\title{
Práticas contemporâneas do design
}

\section{Contemporary practices of design}

\section{Cláudio Boni}

claudioboni@hotmail.com

\author{
Mônica Moura \\ monica.moura@unesp.br
}

Paula da Cruz Landim

paula@faac.unesp.br

\begin{abstract}
Resumo
Novos desafios têm surgido para os designers na contemporaneidade, ao mesmo tempo ocorrem críticas acerca de sua atuação com relação ao envolvimento no mercado e na sociedade. Um dos questionamentos que impera sobre o designer contemporâneo é: como equilibrar a relação entre consumo e necessidades sociais e sustentáveis. Diante disso, é imprescindível investigar a contemporaneidade e o design centrado nas pessoas - conteúdos abordados neste estudo - e o papel do design contemporâneo diante dos desafios globais: sociais e ambientais. Neste cenário, grandes autores questionam o papel dos designers na propagação catastrófica da valorização do capital em detrimento da estabilização econômica, mesmo que sacrificando os aspectos culturais da sociedade. Os designers têm a oportunidade de ser provedores de soluções criativas e colaborativas, que contribuam com a resolução de problemas, causados por eles mesmos, e consequentemente sejam mais ativos no desenvolvimento social.
\end{abstract}

Palavras-chave: design contemporâneo, capitalismo, sociedade

\begin{abstract}
New challenges have arisen for designers in contemporary times, at the same time there are criticisms about their performance regarding involvement in the market and society. The question that prevails about the contemporary designer is: how to balance industry and social needs? Given this, the need arises to investigate contemporaneity and people-centered design contents addressed in this study - and the role of contemporary design in face of global social and environmental challenges. In this scenario, great authors question the role of designers in the catastrophic propagation of capital appreciation over economic stabilization, even sacrificing the cultural aspects of society. Designers have the opportunity to be providers of creative and collaborative solutions, which contribute to the solution of problems, caused by themselves, and consequently to human development.
\end{abstract}

Keywords: contemporary design, capitalism, society 


\section{Introdução}

Na contemporaneidade o indivíduo fixa o olhar em seu tempo, de forma a dar atenção não apenas aos destaques, ao movimento corrente, à tendência, mas ao que não é percebido pelo todo, o contemporâneo é aquele que observa o escuro de seu tempo e não a luz. Neste sentido, o entendimento da contemporaneidade é muito complexo, pois traz, muitas vezes, a aceitação da subversividade, da contracultura e até mesmo do inaceitável. O que se espera de algo contemporâneo é que ele gere uma antinomia com o senso comum. Exemplos disso podem ser facilmente encontrados na história moderna, como o movimento Arts and Crafts, que questionou a atuação dos designers durante a segunda Revolução Industrial; e o Movimento Hippie em seu posicionamento contra os costumes da sociedade conservadora dos EUA na década de 1960.

O sujeito contemporâneo é aquele que pertence ao tempo em que se encontra, pois procura entender as características e os comportamentos que rodeiam todos os envolvidos por ele, contudo, não se alinha às exigências desse tempo, o que o faz ser considerado um sujeito inatual. Este posicionamento do sujeito contemporâneo, de entender os sujeitos na atualidade e se diferenciar deles, de acordo com Agamben (2009), dá condição para que ele se distancie do seu tempo, questionando-o e transformando sua relação com esse tempo. Para o autor, a contemporaneidade se dispõe quase que de forma dialógica com o tempo presente, na promoção concomitante da harmonia com o distanciamento, da dissociação com o anacronismo. Isto é, os sujeitos que estão muito alinhados aos discursos e às linguagens de seu tempo, às aspirações e aos posicionamentos, não são da contemporaneidade, pois sua percepção não lhes permite criar um olhar externo para observá-la.

Com isso, o que se espera dos profissionais de design é uma abordagem mais holística acerca das necessidades contemporâneas da humanidade. O que se começa a entender é que o principal desafio para a sociedade atual não mais depende da produção de artefatos. Em vez disso, é preciso que sejam feitas escolhas que lidam com "quão bom?" em vez de "quanto?". Mas as mudanças (e a consciência das mudanças) estão começando tão altamente aceleradas que tentar dar sentido à própria mudança só tornará a indústria mais superficial. Moral, estética e valores éticos serão envolvidos juntamente com escolhas para qual eles serão aplicados (PAPANEK, 2000). O design deve olhar seu passado, relacionar todas as suas atividades que têm gerado saldos positivos, de modo a elencar as reais necessidades do presente e, heterodoxo ao sistema capitalista do consumismo, projetar futuros melhores para a humanidade e para o planeta.

Este estudo objetiva trazer reflexão ao campo do design e adjacências acerca do real papel daqueles que se prestam a melhorar a vida das pessoas. A sociedade tem, hoje, um excesso de informações devido à globalização, forçando os designers a reavaliarem seu papel no ato projetual de soluções - assunto também trazido aqui, como forma de observação às práticas tradicionais dos designers - e de uma análise sob os novos olhares, apresentados por autores diversos, a respeito do papel do design na contemporaneidade. O que se espera com o estudo é 
equilibrar papéis - designer provedor e sociedade consumidora - a fim de se estabelecer um limite na dependência mercadológica, reforçando o olhar para as reais necessidades da sociedade e do planeta.

\section{O disfarce capitalista na contemporaneidade}

Intervenções provindas de diversas áreas têm fomentado o discurso positivista da indústria do consumo, algumas áreas - design, moda, publicidade, entretenimento, show business, entre outras - são usadas estrategicamente como locomotivas na massificação desse discurso, que tem como linguagem a comunicação, os serviços e os produtos sedutores. Essas áreas preconizam, na atualidade, a universalização de experiências estéticas e heterogêneas, que se desenvolvem pela abundância de estilos e signos, movimentando a economia, mas, acima disso, pregam o bem-estar por meio das formas, imagens, narrativas e experiências. Com isso, o estilo, a beleza e o espetáculo se tornaram imperativos na contemporaneidade estética, pois são responsáveis pela elaboração de objetos e serviços que preencherão os mercados do consumo. Além disso, as formas utilizadas pelas marcas para se comunicarem e distribuírem seus produtos, e as das pessoas para os consumir, foram fortemente influenciadas pelo uso exacerbado da produção estética.

Lipovetsky e Serroy (2015) nos dão um exemplo de axioma disposto na contemporaneidade: o uso estratégico da estética pelo capitalismo. Para os autores, na contemporaneidade, a retórica do capitalismo se concretiza por meio da estética, pois há uma famigerada divulgação de comportamentos artísticos, que acontecem em diferentes níveis sociais e culturais. O chamado "capitalismo artista" constrói, então, uma massa de consumidores de arte industrial, de criadores de experiências estéticas e de ativistas do novo modo epicurista de vida. Tudo isso foi suportado pela inserção estratégica e onipresente de grandes lojas de departamento, cinemas (com exclusividade a filmes blockbusters), music-halls, desfiles e fotos de moda, produtos cosméticos, cafés e bistrôs. Nas últimas décadas, o mundo tem se alimentado do hipermodernismo, que traz consigo temperos como a planetarização, a financeirização, a desregulamentação e a excrescência das operações do capitalismo, mas se destaca, ainda, pelo excesso de superficialidade cosmética, o que, para os autores, chama-se inflação estética.

A cultura e a economia, juntamente com a arte e a indústria, tiveram suas barreiras apagadas pelo capitalismo e pela globalização. Por meio de espetáculos artísticos, antes limitados ao universo da arte, as marcas constroem hoje um discurso arraigado de prestações esteticamente midiáticas, que se apoderam de aspectos culturais de povos de um extremo do globo terrestre e os convertem em texturas, tecidos e ritmos eletrônicos para serem fornecidos ao outro extremo. Com isso, a economia se funde à cultura e vice-versa, a exemplo dos artesãos japoneses, que veem sua arte ser produzida nas indústrias chinesas e consumidas por estrangeiros em barracas 
no centro de São Paulo. Sob a égide da promoção social e econômica, a arte se vê fornecedora da produção em série, intercambiada pelos designers, que encontram em seu facciosismo artista um modo de "beneficiar" ambos os lados, cultura e economia.

Os autores lembram, ainda, que a economia baseada na ordem estética da vida cotidiana se originou no capitalismo, em que marcas usam como armas imagens da realidade regadas por uma atmosfera estético-emocional, de forma a construir um mundo ideal e possível para as pessoas. O capitalismo artista, ou "capitalismo criativo transestético", está baseado na promoção crescente de comercialização da sensibilidade e do design, que se operam através de um trabalho orquestrado de injeção de arte no mercado, onde são oferecidos bens, serviços e lugares com forte apelo estético. Neste cenário, o capitalismo mostra um lado muito mais agradável, mesmo que caótico em termos econômicos, pois o cotidiano se torna desejável. A discrepância entre a realidade e a imagem criada para abastecer o capitalismo artista alimenta um cenário insidioso de sucesso, em que indivíduos comuns acreditam viver como artistas por meio das redes sociais, em que outras que mal suprem suas necessidades básicas consomem roupas de marcas famosas.

As inverdades são "fatos" sempre trazidos pela contemporaneidade, que operam por meio de paradigmas difíceis de serem questionados ou confrontados. No capitalismo contemporâneo, os especialistas estão sempre declarando a existência de uma bolha especulativa, o que muitas vezes tem sido responsável pelo surgimento de crises econômicas. Entretanto, é importante que se diga que nem todas as bolhas se envolvem em crises. A bolha da estetização está presente em todas as classes sociais e é sustentada pelo capitalismo do hiperconsumo. $\mathrm{O}$ entendimento deste cenário é preconizado pelo olhar contemporâneo acerca da atualidade e deve ser entendido como uma forma de poder capitalista. A imagem estetizada corrobora o paradigma hedonista do capitalismo, escondendo seus aspectos negativos, que podem ser vistos em forma de destruição social, ambiental, sustentável.

Essa camuflagem estética, utilizada pelo capitalismo, deve ser vista como uma forma de dominação social, isto é, um dispositivo (de poder). Para Agamben (2009), os dispositivos são sempre identificados em uma relação entre dois ou mais atores, em que um se sobrepõe ao outro, em uma relação de neutralização. Essa neutralização pode se dar de várias formas, estabelecendo-se uma comunicação ou não, mas que sempre faz com que o lado oprimido se sinta impedido ou ameaçado pelo outro. Exemplos de dispositivos comumente encontrados na sociedade são os discursos, as instituições, as proposições filosóficas, as leis, a diferença social e até o conhecimento. $\mathrm{O}$ autor revela, ainda, que dispositivo é "qualquer coisa que tenha de algum modo a capacidade de capturar, orientar, determinar, interceptar, modelar, controlar e assegurar os gestos, as condutas, as opiniões e os discursos dos seres viventes" (AGAMBEN, 2009, p.40). Com isso, deve-se entender que não apenas prisões, manicômios, igrejas e senzalas são dispositivos, mas as escolas, as fábricas, as leis, a publicidade, as telenovelas, as revistas de moda, os remédios e muitas outras coisas presentes no cotidiano social. 
De forma análoga, o design também deve ser visto como um dispositivo ou pelo menos um suporte. Manzini (2015) traz uma importante lembrança relacionada ao momento econômico em que a humanidade se encontra, no qual o design tem um importante papel. Ele lembra que há mais de 2.500 anos Lao Tzu escreveu: "Dê a um homem um peixe e você vai alimentá-lo por um dia. Ensine um homem a pescar e você vai alimentá-lo pelo resto da vida" (Tao Te Ching). Ele quis dizer duas coisas: que, para garantir bem-estar duradouro para as pessoas, nós devemos fazer o possível para que elas sejam ativas e capazes de lidar com seus próprios problemas; e que o acesso ao conhecimento e às ferramentas apropriadas deve ser garantido. Essa sabedoria ancestral tem um importante significado na atualidade, em resposta a dois paradigmas errados as ideias de bem-estar e de crescimento econômico - que nos guiaram até o momento, e que foram fortemente ilustrados pela ideia de globalização e massificação da estética.

$\mathrm{Na}$ verdade, no último século, a ideia dominante, que atravessou o mundo pelo princípio ocidental, foi: "Se alguém tem fome dê a ele fast-food ou uma lata de comida pronta para comer (ou, se ele quer mais ação, dê um restaurante luxuoso)" (MANZINI, 2015, p. 94). Indiferentemente do que for fazer, dê a ele alguma coisa que não exija esforços, nenhum raciocínio, nenhum conhecimento de como preparar comida; alguma coisa que impulsione as atividades econômicas ao redor da preparação de comida. Isto é, dê a ele alguma coisa que o guie para a redução da informalidade econômica da autoprodução e troca não monetária, de modo a aumentar a economia regulamentada, para reunir uma demanda que produza e entregue os serviços e produtos necessários. O autor faz um pedido aos designers que se posicionem contra a corrente do incentivo ao consumo através do design, que atua, muitas vezes, de forma inconsciente e inescrupulosa.

Neste discurso positivista do capitalismo do espetáculo, há outro aspecto que ainda não foi bem contado para a sociedade e que vem sendo fortemente estetizado pela mídia: a relação capitalismo x natureza. A descoberta do mundo finito assustou a humanidade nas décadas de 1970-80, que foi mais bem assimilada quando a excrescência de dejetos industriais se tornou um obstáculo para o andamento do progresso. Com isso, a atenção ao meio ambiente se tornou um grande problema para empresas e nações a partir dos anos 2000. Essa heteronomia ecológica coloca a indústria e o design no centro das atenções, pois são grandes atores neste cenário de devastação do meio ambiente (LIPOVETSKY; SERROY, 2015). Para Papanek (2000), todos os sistemas - capitalismo privado, estado socialista e economias mistas - foram construídos sob a hipótese que nós devemos comprar mais, consumir mais, gastar mais, descartar mais longe. Design, para ser ecologicamente responsável, deve ser independente da preocupação do produto nacional grosseiro (não importa quão grosseiro ele possa ser). É importante salientar que na poluição (e na desigualdade social), o designer é severamente envolvido como qualquer um.

Por fim, é imprescindível que a sociedade desenvolva um olhar acerca dos dispositivos impostos pelo capitalismo na disseminação de bens de consumo, criados e suportados pelos designers, através do uso estratégico da estética. O design trouxe uma enormidade de contribuições provindas da arte, convertidas em signos comerciais, com um discurso 
preponderantemente hedonista. Com isso, o capitalismo ofuscou o olhar da sociedade para as consequências de suas ações - devastação ambiental, social e política - apresentando um universo cultural arraigado de possibilidades sensíveis e experienciais. Cabe, ainda, entender se o design que suporta o capitalismo artista é contemporâneo, pois se enquadra no movimento transestético corrente, dominado pelas ideias de benefício econômico, de globalização cultural e de democratização dos bens industrializados.

\section{O design: para objetos ou para pessoas?}

Nos últimos anos, os termos "design" e "designers" têm sido aplicados, com êxito, respectivamente, à noção e às atividades e às pessoas, que estão além daquelas encontradas na comunidade, tradicionalmente reconhecidas por esses termos. O resultado é que o design é hoje reconhecido pelo aumento crescente de pessoas cujo modo de pensar e de comportamento se aplica em muitas situações. Por outro lado, seu significado tem se tornado menos claro do que aparentava ser (para aqueles da área) no passado. Então, nos dias de hoje, por esse grande aumento no uso do design, ele corresponde a um grande espectro de significados e potenciais mal-entendidos (MANZINI, 2015). A verdade é que o designer entendeu que as pessoas não expressam reação às qualidades físicas dos artefatos, mas ao que eles representam, isto é, ao seu significado. Neste sentido, os designers assumem o dever de projetar o intangível, o simbólico, o social, e não apenas objetos fruto da industrialização. Com isso, os objetos são agora criados para públicos de todos os níveis intelectuais e sociais, e não apenas para pessoas racionais e críticas, que quantificam as características físicas e funcionais dos produtos.

A premissa que se deve ter do design, acima das questões projetuais, é a de que ele trabalha para as pessoas, considerando suas histórias de vida e suprimindo suas necessidades, e não para os objetos, focando apenas as questões físicas e simbólicas. Essa antinomia entre o design para as pessoas e o design para os objetos reforça a reflexão acerca do real papel do design perante a maneira como vemos, interpretamos e usamos os objetos. O projeto de design deve considerar as aspirações subjetivas dos usuários, como a memória, a emoção e a interpretação, resultantes da relação da pessoa com o objeto. A isso, dá-se o nome de design centrado no ser humano, que se difere da abordagem que visa apenas a funcionalidade, o custo, a durabilidade, a ergonomia e a estética parametrizada (KRIPPENDORFF, 2000). As pessoas, consideradas pelo design como usuários, muitas vezes não veem relação ou significado em produtos que são comumente ofertados nas prateleiras das lojas.

Papanek (2000) afirma que hoje há uma enormidade de objetos de uso diário, produzidos em massa para um padrão de utilidade e estética completamente desvinculados das reais necessidades dos usuários. A projetação de artefatos tem dado maior ênfase às exigências da indústria que às das pessoas. A escolha de um determinado material, como um tecido para um 
vestido, está mais sujeita à reprovação por questões financeiras e/ou produtivas do que pelo valor emocional que tem para os consumidores. O que se vê são lançamentos de tendências impostas pelos fornecedores, suportadas pelos veículos de comunicação, através de campanhas de forte apelo emocional. Essa publicidade do consumo, na contemporaneidade, vem maquiada pela ideia de experiência de vida, em que tudo se resume ao princípio da geração de valor para os usuários, mas que, quando massificada, perde o sentido de experiência individual.

Krippendorff (2000) faz uma severa crítica à atuação dos designers principalmente no século passado, quando o design se desenvolveu com o discurso, suportado pela indústria, de que a tecnologia, por exemplo, era imprescindível para a evolução humana. Ao invés de as indústrias e os designers adaptarem os produtos às necessidades das pessoas, forçavam as pessoas a se adaptarem aos produtos tecnológicos, garantindo o desenvolvimento econômico empresarial, abertura de novos mercados e o domínio cultural. Isto é, o capital era o foco do mercado, e o design foi o meio facilitador de obtenção do capital, indiferentemente da qualidade de vida das pessoas e dos problemas ambientais. A indústria deu suporte ao crescimento do design, e viceversa, em uma relação de quase dependência. Quase um século se passou após a segunda fase da Revolução Industrial e a maior parte dos designers pouco fez longe da indústria, e pior, sempre propagaram o discurso humanista dos bens de consumo democratizados.

Mesmo não tendo atingido seu principal objetivo, que era o de colaborar ou gerar uma revolução social, o design promoveu um grande impacto na vida dos indivíduos e da sociedade como um todo, produzindo situações de prazer na busca pelo hedonismo. Isso direcionou o modo de vida das pessoas ao individualismo extremo, chamado por Lipovetsky e Serroy (2015) de individualização hiperbólica, que se fundamentou por meio do consumo. Entretanto, os autores assumem que o design não é unicamente uma fonte geradora de sistemas simbólicos produtos e serviços que promovem experiências no uso de significados. O design, para eles, dá condição para que indivíduos e grupos se apoderem do ato criador, na produção de novas estéticas do corpo, de novos entendimentos e até de uma dialógica em torno do usuário-criador, instigada por novas percepções e aspirações que circundam seu modo de vida.

Além disso, o cenário de preocupação ecológica fez com que os designers atuassem de forma dissidente: comércio ou meio ambiente? Norteados pelo capitalismo artista, em que a fabricação de produtos cosméticos e efêmeros é a regra, os designers se veem questionados e apontados como promotores da produção em massa de lixo e da extração inconsequente dos recursos naturais (LIPOVETSKY; SERROY, 2015). Os consumidores, por sua vez, são pegos pela experiência emocional na busca incessante por produtos e serviços com forte teor hedonista e sensível, que se renovam e promovem bem-estar, atingindo todos os sentidos do homem. A estética foi a forma diletante encontrada pelo capitalismo (por meio do design) de fazer os indivíduos se tornarem consumidores, para embarcarem em massa nas experiências musicais, cinematográficas, imagéticas, de turismo, de design, de luxo, e não se atentarem aos malefícios consequentes. 
Os designers não deveriam fazer parte disso, nem serem motivadores dessa degradação social e ambiental, que promove a segregação entre classes para o enriquecimento das marcas. Para Krippendorff (2000), o que deve nortear o trabalho dos designers é o ato de projetar um futuro que seja bom para todos, tendo o passado apenas como uma referência. Neste sentido, o design deve criar um discurso, convencendo a sociedade, que relate possibilidades imaginadas pelos stakeholders (atores) através da mudança criada por eles mesmos de forma coletiva, em que são utilizadas metodologias e práticas do design. Os designers deveriam, então, agir como agentes integradores e/ou coordenadores de projetos em que as ferramentas do design fossem empregadas com foco na melhoria de vida das pessoas de forma ecológica.

Infelizmente, os designers não correspondem às necessidades de uma nação, no quesito desenvolvimento humano, como revela Papanek (2000). Para ele, as cidades do interior e áreas rurais, as ferramentas educacionais que são utilizadas em mais de $90 \%$ do nosso sistema escolar, os hospitais, consultórios médicos, aparelhos de diagnósticos, ferramentas para o campo, e assim por diante, sofrem com negligência do design. Novos designs podem ocorrer esporadicamente nessas áreas, mas normalmente apenas como um resultado do avanço de uma pesquisa, e não como uma resposta genuína para uma real necessidade. Segundo o autor, a sociedade deve se considerar servida pelos designers apenas na parte do topo do triângulo (figura 1), onde se vê mais o show business e os espetáculos do que a efetiva atuação de um designer para a resolução de um problema que atrapalha drasticamente a vida das pessoas.

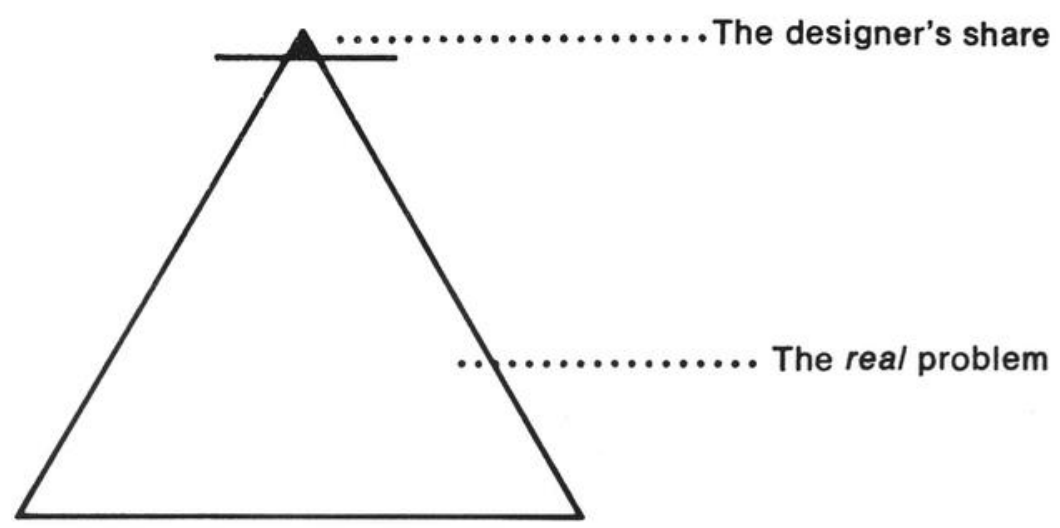

Figura 1 - Discurso dos designers x Problemas reais. Fonte: Papanek (2000).

Segundo o autor, muitos anos de experiência o convenceram de que "especialistas instantâneos" nunca resolvem um problema em sua totalidade. Quando especialistas estrangeiros (especialmente designers) são trazidos para países em desenvolvimento e se deparam com novos problemas, eles frequentemente estão habilitados a fornecer respostas que parecem sensíveis e viáveis. Sua aparente capacidade para penetrar no real problema é ilusória: eles não têm familiaridade com a cultura local do país, com a religião e os tabus sociais, os dados econômicos e muitas outras considerações locais, mas eles ainda dão respostas que parecem ser convincentes. $\mathrm{O}$ que se vê é um processo performático, similar a um espetáculo, em que se busca mais a famigerada estetização das técnicas do que o envolvimento real no 
problema e o desenvolvimento de uma solução que traga melhoria na vida das pessoas de forma efetiva.

Projetos de design ligados ao desenvolvimento humano normalmente têm resultados em longo prazo, pois atuam em esferas complexas e inter-relacionais, como a educação, o território, a memória, a economia e a cultura. Com isso, fica difícil para os designers assumirem a resolução de um problema desse porte, por meio do fornecimento de um produto ou serviço concebido apenas pela intervenção estética ou com apelo comercial. Ao envolver as questões culturais dos indivíduos em um projeto, deve-se levar em consideração todo o histórico social daquele povo. Quando aspectos relacionados à cultura e à individualidade são empregados em um projeto de design, estes não são passíveis de mensuração, diferentemente de prestações ligadas ao objeto, que podem ser analisadas, dimensionadas e separadas sem relação com o usuário (KRIPPENDORFF, 2000).

Por fim, é importante que se entenda que o design tem abarcado todas as questões acerca dos produtos na contemporaneidade, mesmo aquelas mais banais, como um pano de limpar o chão, que têm em sua concepção a intervenção de um designer, consegue fornecer aspectos estilísticos com a promessa da melhora da experiência do usuário. Neste cenário, a indústria do consumo se molda para processar essa atividade - o design - e se enquadrar nas novas demandas do capitalismo transestético (LIPOVETSKY, 2015). O que se sabe, de acordo com Krippendorff (2000), é que o princípio utilizado pelos designers, de projetar produtos funcionais e voltados à produção em série, não faz mais parte de suas atividades contemporâneas, pois isso tem sido assumido pela engenharia, em função de ser um princípio totalmente industrial. A parametrização do processo de design, a massificação das tendências e a promoção do consumo como estilo de vida já são dispositivos do sistema capitalista da atualidade, o que exige novos rumos para o design.

\section{O design para o ser humano}

Uma das mais contundentes observações de Lipovetsky e Serroy (2015) é o fato de o design moderno (e, também, o contemporâneo) ter se constituído sobre o discurso de que a indústria e o capitalismo haviam deixado marcas de destruição na sociedade e no meio ambiente. Com isso, o papel do design passa agora a ser o de reconstruir o mundo social e ecologicamente correto, por meio da junção da arte e da indústria, do artista e do artesão, do prazer e da vida. Há, no entanto, necessidade de se explanar que o design continua trabalhando para a indústria do consumo e focado no fornecimento do bem-estar para as pessoas individualmente, o que promove o consumo das experiências fornecidas pelas empresas. A atuação comercial dos designers não deve ser banida, tampouco desprezada, pois muitos objetos e sistemas desenvolvidos no último século pelos designers ajudaram a melhorar a vida das pessoas. 
Os designers devem ser conscientes de sua responsabilidade social e moral (e planetária). O design é a ferramenta ainda mais poderosa dada aos homens para que eles deem forma a seus produtos, seu ambiente e, por extensão, a si mesmos. O designer deve analisar o passado assim como o futuro previsível de seus atos, ou seja, projetar consciente e efetivamente. Isso é difícil já que muitas vezes a vida dos designers foi condicionada pela orientação de mercado e o sistema de lucro direto, e uma saída radical de tal sistema de valores manipulados é difícil de alcançar. É importante que a área do design tenha um melhor relacionamento com áreas que já atuam no desenvolvimento humano, em relação a situações complexas e vitais, como a área da saúde, da assistência social, da psicologia e outras mais, em atuações transdisciplinares.

Papanek (2000) nos dá, ainda, um exemplo de como essa relação com outras áreas poderia ocorrer no design. Para ele, se um designer industrial ou um escritório de design fosse especializado exclusivamente na área de necessidades humanas, em que consistiria a sua carga de trabalho? Haveria o design de auxílio didático para ser usado em escolas pré-maternais, maternais, jardins da infância, escolas primárias e secundárias, colégios juniores, colégios e universidades, pesquisas de graduação e pós-doutorado e programas de estudos; ou acrescentando habilidades totalmente novas para pessoas que sofrem transformações radicais em seus hábitats: das favelas, guetos, ou da pobreza rural para as cidades; ou das redondezas de uma tribo aborígene na Austrália para a vida da sociedade tecnocrática; da Terra para o espaço; da tranquilidade dos campos ingleses para a vida no Ártico.

As áreas da saúde e das questões humanitárias também poderiam ser melhor beneficiadas pelos designers, tanto pelo design de objetos quanto de serviços. Por exemplo, no desenvolvimento de um termômetro caseiro para leitura da febre, ou dispositivos exóticos como uma máquina coração-pulmão, marca-passo cardíaco, órgãos artificiais e implantes ciborgues, e voltando novamente para o humilde mecanismo de leitura para cegos (código braile), estetoscópios melhorados e dispositivos de análise de urina, aparelhos auditivos e portacomprimidos programados melhorados. $O$ design se preocuparia com dispositivos de salvamento para as casas, indústrias, transporte, e muitas outras áreas e com a poluição, química e térmica, dos rios, córregos, lagos e oceanos, assim como com a do ar. Isso certamente seria a melhor maneira de o design se posicionar como uma área das ciências sociais, e não no fornecimento de soluções facciosas ou indiciosas, em que o usuário não se vê representado.

As pessoas para as quais o design trabalha devem entender o seu papel, assim como seu processo de trabalho. O que faz e para que faz. Segundo Krippendorff (2000), a sociedade se desenvolveu por meio da linguagem, por isso os designers não devem abrir mão de produzirem artefatos sem estabelecer uma comunicação com os usuários. As narrativas e diálogos, que promovem os significados sociais, devem ser a base para a criação e coordenação de projetos. Fazer design deve ser visto quase que como contar uma história, com uma linguagem bem empregada e signos que promovam significados às pessoas. $\mathrm{O}$ ato de projetar deve também fazer parte do discurso, pois até mesmo os usuários participam deste processo na contemporaneidade. $\mathrm{O}$ ato de projetar deixou de ser um privilégio da ciência na modernidade, 
passando a integrar o cotidiano das pessoas em sua vida doméstica. Hoje, as pessoas mais leigas têm informações e ferramentas suficientes para solucionarem problemas por meio da projetação.

Com isso, fazer design é visto hoje como uma atividade de várias áreas, até mesmo da vida doméstica, de forma generalizada. Parte dos designers já tem desenvolvido soluções utilizandose da criatividade e contribuições das pessoas comuns, que muitas vezes vivem os problemas ou estão envolvidas de alguma forma. O processo de design é algo que os designers administram melhor que outros profissionais, mas fazer design já não é mais uma especificidade dos profissionais da área. O papel dos designers especialistas é o de participar com suas habilidades e destrezas, e com sua cultura especial e visão do mundo na construção de uma plataforma de ações e sistemas sensoriais que dá às pessoas e a grupos sociais condição de fazer parte, gerando uma grande possibilidade de ser o que eles querem ser e fazer o que eles querem fazer. Em outras palavras, isso deve dar a eles uma grande possibilidade de definir e colocar (ou ao menos tentar colocar) em prática seus próprios projetos de vida, em um modo ativo e cooperativo (MANZINI, 2015).

Em vez de se trabalhar com usuários individualmente, como muitas vezes ocorre em projetos de design, Krippendorff (2000) recomenda que sejam feitas abordagens com comunidades, pois as chances de se encontrar novidades são ampliadas. O design centrado no humano, para o autor, não é a criação de algo para ou com um indivíduo específico, mas com grupos de características semelhantes e comunidades. Além disso, a colaboração entre os usuários passa a ser realizada com auxílio da tecnologia, quando devidamente utilizada. As pessoas nativas de países em desenvolvimento, por exemplo, têm uma enorme expertise em tecnologia e em design. Incrivelmente, o trabalho de especialistas estrangeiros pode constituir uma intrusão desnecessária. Problemas podem ser agora resolvidos de um jeito melhor por designers e arquitetos locais que são mais familiarizados com os modos locais e consequentemente garantem melhores rendimentos e soluções mais apropriadas, em vez de rápidas e tentadoras propostas com risco de eventuais desapontamentos (PAPANEK, 2000).

De modo geral, quando as pessoas - especialistas ou não - desejam falar sobre design ou mais especificamente sobre o que o design faz, muitas vezes começam com a definição que Herbert Simon dá em seu livro "The sciences of the artificial". Ele escreve que design "é preocupado com como as coisas devem ser - quão importante deveria ser no sentido de atingir os objetivos e a função" (1996, p. 4). A mais imediata e comum interpretação dessa afirmação vincula o conceito de design com aquele de solução para problemas e vê design como um solucionador de problemas, um agente para solucionar problemas em todos os níveis, desde aqueles da vida cotidiana até aqueles de escala global (MANZINI, 2015). A interpretação do que o design pode fazer, embora importante e largamente expressada, não é apenas uma: podese também destacar seu papel no campo da cultura e, portanto, na linguagem e no significado, o que não pode ser feito por qualquer um.

O autor reforça ainda com a seguinte afirmação: todo talento humano pode evoluir dentro de uma habilidade e algumas vezes dentro de uma disciplina (significando uma cultura, 
ferramentas e práticas profissionais) - todos podem correr, mas nem todos podem fazer parte de uma maratona e poucos se tornam atletas profissionais; todos podem tirar uma batida com um tamborim, mas nem todos tocam em um grupo e poucos fazem uma apresentação ao vivo profissionalmente. Similarmente, todos são dotados de habilidades para o design, mas nem todos são designers competentes e poucos se tornam designers profissionais. Aqui se debruça sobre uma definição do campo de possibilidades para aqueles que projetam, entre dois polos do design difuso e do design de especialistas. O design difuso é conduzido por não especialistas, com suas capacidades naturais para o design, enquanto o design de especialistas é de pessoas preparadas para operar profissionalmente como designers, e que os coloca à frente dos projetos como profissionais de design. É claro que esses dois polos com seus perfis correspondentes são uma abstração: o que nos interessa é a extensão do campo de possibilidades que eles indicam, a variedade infinita que pode aparecer dentro deles e especialmente de suas dinâmicas sociais.

A atuação conjunta desses dois estados do design visa unicamente à geração de soluções por meio do conhecimento daqueles envolvidos no problema. Neste sentido, o design propõe não apenas uma solução, mas um propósito, que acaba se tornando político, por instigar em seus interlocutores um discurso da defesa de um futuro projetado por eles e não para eles. Por isso, ensinar os princípios do design centrado no ser humano deve levar em consideração sempre a participação das pessoas que estão dentro do sistema, e não apenas consultores e ou especialistas (KRIPPENDORFF, 2000). Além disso, um dos aspectos do design centrado no ser humano estabelece a princípio de que os designers não são autossuficientes, tampouco mais preparados que os stakeholders (usuários, vítimas, engenheiros, profissionais etc.). Deve-se reforçar, então, a importância de as pessoas entenderem o papel dos designers em um projeto, que deve ser estabelecida pelos próprios designers.

Para Papanek (2000), a mais importante capacidade que um designer pode trazer ao seu trabalho é a habilidade de reconhecer, isolar, definir e resolver problemas. No seu ponto de vista, designs devem ser sensíveis para quais problemas existem. Frequentemente designers vão descobrir a existência de um problema que ninguém descobriu, definiu e, então, tentam uma solução. O número de problemas, assim como sua complexidade, aumentou a tal ponto que novas e melhores soluções são exigidas. Para isso, Krippendorff (2000) apresenta como solução o trabalho colaborativo dos designers. Os designers devem inter-relacionar os conhecimentos envolvidos no projeto - dos stakeholders - de forma a sentir-se à vontade com o desconhecimento ou o novo conhecimento. Com isso, o designer se posiciona como um líder de projeto, que faz uso de métodos e técnicas que estão no conjunto de ferramentas de sua área, mas que são todas administradas com foco principalmente nas pessoas, e não nas máquinas, nos objetos e nas marcas.

O método de design significa o resultado da combinação de três qualidades humanas: senso crítico (a habilidade para olhar o estado das coisas e reconhecer o que não pode ou não deveria ser aceitável), criatividade (a habilidade humana para imaginar alguma coisa que não existe ainda), e o senso prático (a habilidade para reconhecer modos operacionalizáveis de conseguir 
fazer as coisas acontecerem). Ao se integrar os três feitos, é possível imaginar alguma coisa que não está lá, mas que poderia estar se as ações apropriadas fossem realizadas (MANZINI, 2015). Trazer melhorias para a vida das pessoas de forma nunca antes vista é algo que facilmente pode ser administrado pelos designers, quando se inserem em comunidades para resolverem problemas de difícil solução, mas tais melhorias só podem ser obtidas por meio da participação dos atores principais. O design é uma área que fomenta a inovação social e isso deve ser algo mais bem definido na própria formação dos profissionais.

No âmbito da inovação social, as pessoas, guiadas pela necessidade ou pelo desejo de sua capacidade natural de projetar, e sustentadas pela difusão das mídias digitais e da conectividade, tomaram parte ativamente e colaboraram para criar novas formas de organização (comunidades criativas e organizações colaborativas), participando em massa na solução de problemas complexos e se tornando produtoras de conteúdo para as novas redes digitais. Olhando para essas tendências emergentes, especificamente no mapa do método de design, pode-se dizer, como afirma ainda Manzini, que vários indivíduos e grupos desenvolvendo novas habilidades de design estão se movendo da área do design difuso para o design de especialistas, se encaixando de forma muito dinâmica no centro do mapa: o número de atores não especialistas que estão, todavia, habilitados e com experiência em design está crescendo. Essas pessoas, que estão operando no modo difuso, mas competente do design, estão interagindo com um crescente número de designers especialistas que estão dispostos a acompanhá-las no processo de design.

A tecnologia é um grande exemplo da interação de designers especialistas e não especialistas. $\mathrm{Na}$ atualidade, as pessoas têm mais controle da tecnologia tanto no uso quanto na sua produção (projetação), fazendo com que os designers não sejam mais responsáveis pelo futuro de suas ideias. Para Krippendorff (2000), a única coisa a ser feita pelos designers na contemporaneidade é se posicionar no futuro, bem à frente da sociedade. Isso acaba mudando o objetivo do design no desenvolvimento de produtos, bens e serviços, pois exige que o contexto social seja considerado em primeiro plano, servindo de base para a melhoria da tecnologia, que vem depois. Os diversos atores de um sistema fazem uso coletivamente das tecnologias de forma ecológica, e isso deve ser observado pelo design centrado no ser humano. O sucesso de iniciativas de design voltadas à inovação social, fazendo uso ou não de alta tecnologia, baseia-se principalmente na colaboração entre usuários e profissionais.

De acordo com Manzini (2015), ao se observar iniciativas de compartilhamento na sociedade, pode-se encontrar muitas ações de sucesso, como: grupos familiares que decidiram compartilhar alguns serviços para reduzir os custos econômicos e ambientais, mas também para criar novas maneiras de conviver em vizinhança (moradia em comunidade, em que o compartilhamento é feito de várias maneiras e a ajuda é mutua dentro da residência ou da vizinhança); novas formas de realizar trocas ou permutas (de pequenas trocas de coisas a banco de horas de mão de obra especializada e dinheiro local); serviços em que jovens e idosos se ajudam, promovendo uma nova ideia de bem-estar (serviços sociais colaborativos); jardins comunitários configurados e administrados por cidadãos que, ao fazê-lo, melhoram a qualidade 
da cidade e das redes sociais (jardins de guerrilha, jardins comunitários, telhados verdes); são novos modelos de produção baseados nos recursos locais e no engajamento das comunidades locais (negócios sociais); feiras e vendas diretas entre os produtores e consumidores (iniciativa de feiras).

A primeira e mais evidente característica comum nessas iniciativas é que elas emergem da recombinação criativa de ativos existentes (do capital social para a herança histórica, do artesanato tradicional para a tecnologia avançada disponível), que visam alcançar socialmente ganhos reconhecidos de forma diferente. Este é também um traço comum na definição do que é inovação social e por que ela surge. Além disso, a inovação social deve sempre prever uma harmonia não apenas entre as pessoas, mas entre as pessoas e o contexto no qual estão inseridas. Um tipo mais durável de pensamento de design implica ver o produto (ou a ferramenta, ou o dispositivo de transporte, ou a construção, ou a cidade) como um link significativo entre o homem e o meio ambiente. É imperativo que se veja o homem, suas ferramentas, ambiente e modos de pensar e planejar, como um sistema não linear, simultâneo, integrado e totalmente compreensivo.

Para Papanek (2000), esta abordagem holística é uma forma de design integrado. Isso lida com extensões especializadas do homem que fazem com que ele se mantenha um generalista. Todas as funções do homem - respiração, equilíbrio, movimento, percepção, consumo, simbolismo, produção social - estão inter-relacionadas e são interdependentes. Se o objetivo é relacionar o ambiente humano com a totalidade psicofísica do ser humano, será necessário replanejar e reprojetar ambas as funções e estruturas de todas as ferramentas, produtos, abrigos e estabelecimentos do homem em um ambiente de vida integrado, um hábil ambiente para o crescimento, mudança, mutação, adaptação, regeneração, em resposta às necessidades do homem. Design integrado talvez também precise de especialistas - especialmente aqueles não orientados apenas a gerar lucro, mas aqueles humanos e humanitários preocupados com o homem e seu ambiente. Normalmente esse tipo de grupo pode ser composto por designers, antropólogos, sociólogos, psicólogos e outros especialistas das áreas da engenharia. O mais importante é que as pessoas, nas quais o projeto se baseia, sejam representadas pelo seu próprio grupo. Sem a eventual ajuda dos usuários, não é possível fazer um design socialmente aceitável.

Por fim, Manzini (2015) revela que, ao se discorrer sobre cooperação, Sennett ${ }^{1}$ diz que "um suporte mútuo está construído no gene de todos os animais sociais; cooperam para realizar o que eles não poderiam fazer sozinhos". Sendo assim, nós podemos assumir que colaboração é algo intrínseco ao homem, pois é um animal social. Ao mesmo tempo, sendo também animais culturais, nós mudamos ao longo do tempo e do contexto, e, portanto, o modo pelo qual nós colaboramos também muda com o tempo e o contexto. Em particular, ao se falar que cooperação é uma habilidade (que é um artefato social para ser construído, utilizando-se uma

1 SENNETT, Richard. Together: The Rituals, Pleasures and Politics of Cooperation. New Haven (EUA): Yale University Press, 2013. 336 p. 
habilidade específica, no qual pode ser ou aumentado ou perdido), Sennett observa que "sociedade moderna é a junção de pessoas sem habilidades na prática da cooperação".

\section{Conclusão}

Não há dúvidas de que tanto a sociedade quanto o meio ambiente estão sofrendo com o modo como o mercado globalizado tem distribuído seus ativos de consumo. O design entra neste cenário como uma poderosa ferramenta que alimenta o capital com a arte, sobrepondo aspectos culturais e ecológicos, em decorrência da necessidade de promover um mundo hedonista e material. O design dá condições ao capitalismo artista, pois se enquadra no imperativo movimento transestético, que alimenta o conceito de dependência econômica, cultural e de consumo industrial. O design da contemporaneidade deve rever esse ciclo dominante, contribuindo para o mercado e para a sociedade através da promoção do equilíbrio, da criatividade e do verdadeiro desenvolvimento social, ambiental e sustentável.

É importante que o design inicie um trabalho de conscientização global do consumo e do bem-estar social, sinalizando a estética como uma das contribuições para soluções que transcendam a mera troca de capital, evitando as prestações cosméticas acerca de produtos e serviços com a promessa da melhora da experiência das pessoas. Como relatado no texto, o design para a indústria mecânica não corresponde às atividades contemporâneas do design, pois isso tem sido cada vez mais parametrizado por outras áreas. $O$ design contemporâneo é o design que soma a especialização e a difusão dos métodos e técnicas, formando um contexto em que a sociedade faz parte da tomada de soluções para problemas reais para ela mesma. $\mathrm{O}$ design contemporâneo é coletivo e colaborativo, pois isso é uma característica histórica do homem e o designer está dentro deste "guarda-chuva" chamado humanidade.

O design da contemporaneidade deve ser conduzido por políticas e práticas que considerem a cultura e a história locais, garantindo soluções menos quiméricas e mais eficientes para a humanidade. Isso deve ser entendido como uma resposta ao papel negativo que grande parte dos profissionais de design vem desempenhando sob a égide da economia saudável e bem-estar social. O que se espera, com este estudo, é que os designers se desprendam do fluxo mercadológico total e iniciem um processo de auxiliar a sociedade e o mercado concomitantemente, por meio da conscientização, do senso sociocultural e da criatividade coletiva. O designer contemporâneo é o profissional que vive seu tempo e que consegue observá-lo à distância, entendendo o passado, criticando o presente e projetando novas possibilidades de futuro. 


\section{Referências}

AGAMBEN, Giorgio. O que é o contemporâneo? E outros ensaios. Tradução Vinícius Nicastro Honesko. Chapecó SC: Argos, 2009. p. 27-69. ISBN 978-85-7879-005-5.

KRIPPENDORFF, Klaus. Design centrado no ser humano: Uma necessidade cultural. Tradução Gabriela Meirelles. In.: Estudos em design, Rio de janeiro, V. 9, n. 3, p. 87-98, set. 2000.

LIPOVETSKY, Gilles; SERROY, Jean. A estetização do mundo: Viver na era do capitalismo artista. Tradução Eduardo Brandão. São Paulo: Companhia das Letras, 2015. 467 p. ISBN 978-85-359-2569-2.

MANZINI, Ezio. Design, when everybody designs: An introduction to design for social innovation. Cambridge (EUA): The MIT Press, 2015. 241 p. ISBN 978-0-262-02860-8.

PAPANEK, Victor. Design for the real world: Human ecology and social change. 2. ed. Chicago (USA): Academy Chicago publishers, 2000, p. 63-304. ISBN 0-89733-153-2.

\section{Sobre os autores}

\section{Cláudio Boni}

Consultor pela Dessau Design Estratégico; Professor em cursos de graduação e pósgraduação em design. Especialista em Gestão de Design pela Universidade Estadual de Londrina (UEL) em 2006; Mestre e Doutorando em Design pela Universidade Estadual Paulista (UNESP).

claudioboni@hotmail.com

\section{Mônica Moura}

Doutora e Mestre em Comunicação e Semiótica (PUC-SP), Pós-Doutorado em Design Contemporâneo Brasileiro (PUC-Rio), Estágio Pós-doutoral pela Universidade do Minho (UMINHO, Portugal). É Professora Assistente Doutora do Departamento de Design, Professora Credenciada e Orientadora no Programa de Pós-Graduação em Design, UNESP/Bauru; Coordenadora do Laboratório e do Grupo de Pesquisa em Design Contemporâneo: sistemas, objetos e cultura CNPq/UNESP).

monica.moura@unesp.br

\section{Paula da Cruz Landim}

Livre-docente em Design de Produto pela Faculdade de Arquitetura, Artes e Comunicação da Universidade Estadual Paulista, UNESP (FAAC); professora da graduação e do Programa de Pós-Graduação em Design da mesma instituição. Coordenadora do Núcleo de Percepção e Cognição Ambiental (NUPECAM) da Unesp. paula@faac.unesp.br 